\title{
Gambaran status karies dan status gizi pada murid TK Kartika XX-16 Manado
}

\author{
${ }^{1}$ Raissa Y. E. Rengkuan \\ ${ }^{2}$ Pemsi M. Wowor \\ ${ }^{1}$ Christy N. Mintjelungan
}

\author{
${ }^{1}$ Program Studi Pendidikan Dokter Gigi Fakultas Kedokteran \\ ${ }^{2}$ Bagian Farmakologi Fakultas Kedokteran \\ Universitas Sam Ratulangi Manado \\ Email: raissarengkuan@gmail.com
}

\begin{abstract}
Dental caries is a dental hard tissue disease with multifactorial causes. Consumption of food and beverages improperly and less of dental treatment affect dental caries status and nutritional status. This study was aimed to obtain the profile of dental caries status and nutritional status of kindergarten students of Kartika XX-16 Manado. This was a descriptive study with a cross sectional design. Subjects were selected using nonprobability sampling method with consecutive sampling technique. There were 71 students as the total population; 48 students were selected as subjects. Deciduous dental examination was performed to assess the dental caries status using the dmf-t index. Body weight, height, and age were noted to assess the nutritional status using antrophometric indices based on $\mathrm{z}$ score to obtain the body mass index for age (BMI for age). The results showed that the dental caries status of the subjects was at high category (dmf-t index of 4.92). There were 37 subjects (77.1\%) who had caries experience in primary teeth and 11 subjects (22.9\%) with caries-free primary teeth. Of all subjects, $93.75 \%$ had normal nutrition status and $6.3 \%$ had nutritional problems. Conclusion: In general, the kindergarten students of Kartika XX-16 Manado had dental caries status of high category, however, their nutritional status was quite good.
\end{abstract}

Keywords: dental caries status, nutritional status

\begin{abstract}
Abstrak: Karies gigi merupakan suatu penyakit jaringan keras gigi dengan penyebab multifaktorial. Konsumsi makanan dan minuman dengan pola yang tidak tepat, serta kurangnya pemeliharaan kesehatan gigi berdampak pada status gizi dan status karies gigi anak. Penelitian ini bertujuan untuk mengetahui gambaran status karies gigi dan status gizi pada murid TK Kartika XX-16 Manado. Jenis penelitian ialah deskriptif observasional dengan desain potong lintang. Jumlah populasi 70 orang murid dengan subyek 48 anak diperoleh menggunakan metode nonprobability sampling dengan teknik consecutive sampling. Pemeriksaan gigi-geligi sulung untuk menilai status karies gigi. Penilaian status karies gigi menggunakan indeks dmft. Pemeriksaan berat badan, tinggi badan, dan usia untuk menilai status gizi. Penilaian status gizi menggunakan indeks antropometri berdasarkan z-skor terhadap indikator indeks massa tubuh menurut umur (IMT/U). Status karies gigi murid TK Kartika XX-16 Manado berada pada kategori tinggi dengan indeks dmf-t 4,92. Jumlah subyek dengan riwayat karies gigi sulung sebanyak 37 anak $(77,1 \%)$ sedangkan yang bebas karies gigi sulung sebanyak 11 anak (22,9\%). Status gizi murid TK Kartika XX-16 Manado terdiri dari 93,75\% status gizi normal dan 6,3\% bermasalah gizi. Simpulan: Murid TK Kartika XX-16 Manado umumnya mempunyai status karies gigi pada kategori tinggi sedangkan status gizi cukup baik.
\end{abstract}

Kata kunci: status karies gigi, status gizi 
Salah satu penyakit gigi dan mulut pada anak yang masih merupakan masalah ialah karies gigi. World Health Organization (WHO) (2003) menjelaskan bahwa karies gigi masih menjadi masalah utama kesehatan gigi dan mulut di sebagian besar negara industri karena masalah tersebut menyerang $60-90 \%$ anak-anak usia sekolah. Prevalensi karies gigi masih tinggi di berbagai negara, sedangkan di Indonesia prevalensi karies gigi tahun 2007 sebesar 23,4\%. Pada tahun 2013 prevalensi karies gigi sebesar $25,9 \%$ dengan peningkatan prevalensi karies gigi sebesar 2,5\%. ${ }^{1,2} \mathrm{Hal}$ ini menjadikan karies gigi sebagai masalah kesehatan yang penting terutama oleh anak prasekolah. Menurut WHO, anak prasekolah merupakan kelompok usia yang paling berisiko mengalami karies gigi, sebab anak-anak tersebut masih mempunyai perilaku atau kebiasaan diri yang kurang menunjang terhadap kesehatan gigi. ${ }^{3}$

Karies gigi juga merupakan penyakit multifaktorial. Salah satu faktor risiko penyebab karies gigi yaitu status gizi. Status gizi erat kaitannya dengan pola makan. Pola makan makanan kariogenik selain berdampak pada status karies gigi, juga berdampak pada terjadinya masalah status gizi. ${ }^{4,5}$

Status gizi merupakan salah satu indikator derajat kesehatan. Seperti yang termuat dalam Undang-Undang Kesehatan tahun 2009 pasal 142 ayat (1), disebutkan bahwa upaya perbaikan status gizi diprioritaskan untuk kelompok usia rawan seperti anak di bawah lima tahun (balita). ${ }^{6,7}$ Pada anak yang kurang gizi daya tahan tubuhnya rendah sehingga anak sering terkena penyakit infeksi. Secara nasional prevalensi status gizi kekurusan dan berat badan lebih pada anak balita di tahun 2007, masing-masing sebesar $12,1 \%$ dan $7,9 \%$. Pada tahun 2013, secara nasional prevalensi status gizi kekurusan dan berat badan lebih pada anak balita, masingmasing $11,2 \%$ dan 18,8\%. Terjadi penurunan angka prevalensi status gizi kekurusan dan peningkatan angka prevalensi status gizi berat badan lebih pada anak balita sejak tahun 2007 sampai tahun 2013. Dengan kata lain, masalah kesehatan yang dihadapi anak balita di Indonesia ialah masalah status gizi. ${ }^{1,2}$

Anak dengan gigi sulung merupakan anak usia prasekolah yang banyak dijumpai di Taman Kanak-kanak (TK). TK Kartika XX-16 Manado dipilih sebagai lokasi penelitian karena belum pernah dilakukan penelitian seperti ini. Selain itu, dari hasil survei awal di sekolah ini jumlah subyek penelitian banyak sehingga dalam penggeneralisasian hasil penelitian lebih terwakili.

\section{BAHAN DAN METODE PENELITIAN}

Jenis penelitian ini ialah deskriptif observasional dengan desain potong lintang. Penelitian ini berlokasi di TK Kartika XX-16 Teling Atas Kota Manado Provinsi Sulawesi Utara. Waktu Penelitian dilaksanakan pada bulan Juli 2017. Populasi penelitian ini yaitu murid TK Kartika XX-16 Manado tahun ajaran 2016 - 2017 yang berjumlah 70 orang. Metode pengambilan sampel yang digunakan ialah total sampling.

Pada seluruh subyek penelitian dilakukan pemeriksaan gigi yang meliputi pemeriksaan karies dengan menggunakan indikator dmf-t (decayed teeth, missing due to caries, filled-tooth). Penentuan status gizi dinyatakan dalam z-skor berdasarkan berat badan, tinggi badan, dan usia subyek.

\section{HASIL PENELITIAN \\ Karakteristik subyek penelitian}

Sebagian besar subyek terdistribusi pada usia 61-71 bulan sebanyak 39 anak (81,3\%), diikuti usia 48-60 bulan sebanyak 6 anak (12,5\%), dan terakhir usia 72-83 bulan sebanyak 3 anak $(6,2 \%)$ (Tabel 1).

Tabel 1. Distribusi subyek berdasarkan usia

\begin{tabular}{ccc}
\hline $\begin{array}{c}\text { Usia } \\
\text { (bulan) }\end{array}$ & $\begin{array}{c}\text { Frekuensi } \\
(\mathbf{n})\end{array}$ & $\begin{array}{c}\text { Persentase } \\
(\boldsymbol{\%})\end{array}$ \\
\hline $48-60$ & 6 & 12,5 \\
$61-71$ & 39 & 81,3 \\
$72-83$ & 3 & 6,2 \\
Total & 48 & 100,0 \\
\hline
\end{tabular}


Berdasarkan jenis kelamin didapatkan subyek penelitian terdiri dari 22 anak lakilaki $(45,8 \%)$ dan 26 anak perempuan $(54,2 \%)$.

Tabel 2. Distribusi responden menurut jenis kelamin

\begin{tabular}{ccc}
\hline Jenis kelamin & $\begin{array}{c}\text { Frekuensi } \\
\text { (n) }\end{array}$ & $\begin{array}{c}\text { Persentase } \\
(\boldsymbol{\%})\end{array}$ \\
\hline Laki-laki & 22 & 45,8 \\
Perempuan & 26 & 54,2 \\
Total & 48 & 100,0 \\
\hline
\end{tabular}

Status karies gigi dan status gizi subyek penelitian

Status karies gigi subyek berdasarkan pengalaman karies gigi sulung (dmf-t) dan status gizi subyek berdasarkan indeks antropometri dengan indikator IMT/U yang dinyatakan dalam z-skor (Tabel 3 dan Tabel 4).

\section{Distribusi status karies gigi sulung subyek.}

Status karies gigi subyek sebagian besar mengalami decay (78\%) dan tidak ada subyek yang melakukan filled (Tabel $3)$.

Tabel 3. Status karies gigi subyek

\begin{tabular}{ccc}
\hline $\begin{array}{c}\text { Status } \\
\text { karies }\end{array}$ & $\begin{array}{c}\text { Frekuesnsi } \\
(\mathbf{n})\end{array}$ & $\begin{array}{c}\text { Persentase } \\
(\boldsymbol{\%})\end{array}$ \\
\hline Decay & 185 & 78 \\
Missing & 52 & 22 \\
Filling & 0 & 0 \\
Total dmf-t & 237 & 100 \\
\hline
\end{tabular}

Berdasarkan karakteristik jenis kelamin, persentase riwayat karies gigi perempuan $(56,8 \%)$ sedikit lebih tinggi dibandingkan laki-laki (43,2\%) (Tabel 4).

Tabel 4. Status karies gigi berdasarkan karakteristik jenis kelamin

\begin{tabular}{ccc}
\hline $\begin{array}{c}\text { Jenis } \\
\text { kelamin }\end{array}$ & $\begin{array}{c}\text { Jumlah karies } \\
\text { gigi }(\mathbf{n})\end{array}$ & $\begin{array}{c}\text { Prevalensi } \\
(\boldsymbol{\%})\end{array}$ \\
\hline Laki-laki & 16 & 43,2 \\
Perempuan & 21 & 56,8 \\
Total & 37 & 100 \\
\hline
\end{tabular}

Jumlah subyek dengan riwayat karies gigi terbanyak pada kelompok usia 61-71 bulan yaitu sebanyak 33 anak $(84,6 \%)$, diikuti oleh kelompok usia $72-83$ bulan sebanyak 2 anak $(66,7 \%)$, dan kelompok usia 48-60 bulan sebanyak 3 anak (50\%) (Tabel 5).

Tabel 5. Status karies gigi berdasarkan karakteristik usia

\begin{tabular}{ccc}
\hline Usia (bulan) & $\begin{array}{c}\text { Status karies } \\
\text { gigi (n) }\end{array}$ & $\begin{array}{c}\text { Prevalensi } \\
(\boldsymbol{\%})\end{array}$ \\
\hline $48-60$ & 3 & 7,9 \\
$61-71$ & 33 & 86,8 \\
$72-83$ & 2 & 5,3 \\
Total & 38 & 100 \\
\hline
\end{tabular}

\section{Distribusi status gizi subyek}

Hampir semua subyek memiliki status gizi normal $(93,7 \%)$. Subyek yang memiliki masalah status gizi sebanyak 3 anak terdiri dari berat badan kurang (underweight), berat badan lebih (overweight), dan obes; masing-masing satu anak $(2,1 \%)$.

Tabel 6. Status gizi subyek

\begin{tabular}{lcc}
\hline $\begin{array}{l}\text { Status gizi } \\
\text { (IMT/U) }\end{array}$ & $\begin{array}{c}\text { Frekuensi } \\
(\mathbf{n})\end{array}$ & $\begin{array}{c}\text { Prevalensi } \\
(\mathbf{\%})\end{array}$ \\
\hline Berat badan & 1 & 2,1 \\
kurang & & \\
Normal & 45 & 93,7 \\
Berat badan lebih & 1 & 2,1 \\
Obes & 1 & 2,1 \\
Total & 48 & 100 \\
\hline
\end{tabular}

Berdasarkan karakteristik jenis kelamin, masalah status gizi (kurang, berat badan lebih, obes) lebih sering pada subyek berjenis kelamin laki-laki (Tabel 7).

Tabel 7. Status gizi responden berdasarkan jenis kelamin

\begin{tabular}{lcccc}
\hline \multirow{2}{*}{$\begin{array}{c}\text { Jenis } \\
\text { kelamin }\end{array}$} & \multicolumn{2}{c}{ BB kurang } & \multicolumn{2}{c}{ BB lebih } \\
\cline { 2 - 5 }$(\mathrm{n})$ & $(\%)$ & $(\mathrm{n})$ & $(\%)$ \\
\hline Laki-laki & 1 & 4,5 & 2 & 9 \\
Perempuan & 0 & 0 & 0 & 0 \\
Total & 1 & 4,5 & 2 & 9 \\
\hline
\end{tabular}

Berdasarkan karakteristik usia, masalah status gizi berat badan kurang dan 
berat badan lebih bervariasi untuk masingmasing kelompok usia. Berat badan lebih, pada kelompok usia 48-60 bulan sebesar 16,7\%. Pada kelompok usia 61-71 bulan, berat badan lebih $(2,6 \%)$ dan pada kelompok usia $72-83$ bulan berat badan kurang sebesar 33,3\% (Tabel 8).

Tabel 8. Status gizi responden berdasarkan karakteristik usia

\begin{tabular}{ccccc}
\hline \multirow{2}{*}{$\begin{array}{c}\text { Usia } \\
\text { (bulan) }\end{array}$} & \multicolumn{2}{c}{ BB kurang } & \multicolumn{2}{c}{ BB lebih } \\
\cline { 2 - 5 } & $(\mathrm{n})$ & $(\%)$ & $(\mathrm{n})$ & $(\%)$ \\
\hline $48-60$ & 0 & 0 & 1 & 16,7 \\
$61-71$ & 0 & 0 & 1 & 2,6 \\
$72-83$ & 1 & 33,3 & 0 & 0 \\
\hline
\end{tabular}

\section{BAHASAN}

Permasalahan di dałam rongga mulut anak seringkali dipandang sebagai suatu hal yang tidak terlalu penting oleh orang tua. Karakteristik kunjungan pasien gigi anak di Indonesia ialah berkunjung ke dokter gigi setelah menderita sakit sehingga mengganggu aktivitas si anak.

Di Indonesia, indikator derajat kesehatan umum dan kesehatan rongga mulut ialah status gizi dan status karies gigi. ${ }^{6}$ Status gizi untuk menilai keadaan tubuh yang diakibatkan oleh keseimbangan antara asupan gizi dengan kebutuhan sednagkan status karies gigi untuk menilai tingkat keparahan karies pada gigi permanen dan gigi sulung.

Karies gigi pada anak dengan gigi sulung lebih cepat mengalami peningkatan keparahan status karies gigi, dibandingkan anak dengan gigi permanen. Hal ini sejalan dengan penelitian Noya ${ }^{8}$ di Kota Manado pada tahun 2011, yang menunjukkan status karies anak dengan gigi permanen termasuk kategori sedang dengan indeks DMFT 3,04. Hasil penelitian status karies pada anak dengan gigi sulung di TK Kartika XX-16 Manado menunjukkan status karies gigi berada pda kategori tinggi dengan indeks dmf-t 4,92.

Perbedaan tingkat keparahan status karies gigi terkait dengan faktor primer penyebab karies gigi itu sendiri yaitu, mikroorganisme, waktu, gigi, dan diet.
Pada anak dengan gigi sulung yang status karies pada tingkat keparahan tinggi, terjadi kolonisasi awal oleh mikroorganisme Streptococcus mutans. Kolonisasi awal pada usia yang lebih dini menyebabkan tingkat Sterptococcus mutans dałam rongga mulut anak meningkat, yang akhirnya berdampak pada tingginya status karies pada anak dengan gigi sulung. Struktur enamel gigi sulung tidak sepadat gigi permanen. Kepadatan enamel gigi bergantung pada kadar mineral. Struktur enamel gigi sulung lebih banyak bahan organik dan air sedangkan jumlah mineralnya sedikit. Struktur enamel gigi permanen mengandung $1 \%$ air, $2 \%$ bahan organik, dan $97 \%$ mineral. ${ }^{4}$

Kepadatan struktur enamel sangat menentukan kelarutan gigi. Gigi sulung lebih muda terserang karies daripada gigi permanen, disebabkan kadar mineralnya pada enamel lebih sedikit daripada gigi permanen. Ditinjau dari faktor diet yaitu pola makan kariogenik (jumlah, fekuensi, jenis) yang tinggi, misalnya permen merupakan risiko yang erat kaitannya terhadap karies pada gigi sulung. Faktor lain juga berperan yaitu menyikat gigi dalam hal kontrol plak. ${ }^{9}$

Penelitian terbaru mengungkapkan, kontrol plak secara alamiah dengan memakan buah nanas dapat mengurangi risiko terjadinya karies pada anak dengan gigi sulung. ${ }^{10}$ Hal ini menunjukkan selain mengatur pola makan yang tepat, kontrol plak yang benar merupakan upaya yang relevan terhadap pencegahan karies pada gigi sulung.

Status karies gigi murid pada TK Kartika XX-16 Manado berada pada kategori tinggi dengan indeks dmft 4,92. Hal ini juga menyimpulkan rerata jumlah kerusakan gigi sebanyak 5 buah gigi setiap orang. Jumlah kerusakan gigi memiliki total skor dmf-t 237 (Tabel 6). Distribusi total skor dmft terbanyak pada komponen decay.

Distribusi total skor dmft dhitung untuk masing-masing responden. Jumlah subyek yang bebas karies gigi sulung sebanyak 11 anak (22,9\%) sedangkan 
jumlah subyek yang memiliki riwayat karies gigi sulung sebanyak 38 anak $(79,2 \%)$

Pengalaman karies sedikit lebih tinggi pada perempuan dibandingkan laki-laki (Tabel 6). Hasil serupa ditunjukan oleh penelitian yang dilakukan oleh $\mathrm{Pulu}^{11}$ di SD GMIM 21 Eben Haezar Manado yang melaporkan bahwa perempuan memiliki riwayat karies gigi yang sedikit lebih tinggi daripada laki-laki. Penelitian lain oleh Bermulo $^{12}$ terhadap anak SD di Deşa Ranowangko Kecamatan Kombi menunjukkan perempuan juga memiliki risiko keparahan karies gigi yang tinggi. Tingginya riwayat karies gigi responden laki-laki dibandingkan pada responden perempuan menunjukkan faktor jenis kelamin tidak banyak memengaruhi karies gigi.

Prevalensi riwayat karies gigi berdasarkan karakteristik usia, menunjukkan kecenderungan terhadap usia subyek. Semakin tinggi usia, semakin meningkat jumlah subyek dengan riwayat karies gigi . Peningkatan prevalensi riwayat karies terhadap usia subyek, dikarenakan subyek sedang berada pada masa pertumbuhan gigi sulung.

Masa pertumbuhan gigi sulung merupakan masa dimana pertumbuhan dan perkembangan mikroorganisme terutama Streptococcus mutans sangat rentan teriadi. Semakin bertambahnya usia, semakin lama gigi terpapar dalam rongga mulut sehingga semakin tinggi risiko terjadinya karies gigi. Anak-anak berobat ke dokter gigi secara periodik, tidak perlu takut. Penelitian oleh Inkiriwang ${ }^{13}$ mendapatkan hasil yang tinggi (71\%) dari anak yang takut ke dokter gigi.

Perhatian yang maksimal untuk melakukan pencegahan dini terhadap karies gigi sangat dibutuhkan oleh seluruh subyek. Pencegahan dini yang efektif bagi anak dapat dimulai sedini mungkin dengan membentuk perilaku pemeliharaan kesehatan rongga mulut oleh orangtua dan lingkungan sekolah, yang penting bagi kesehatan anak secara umum dan juga kesehatan gigi.

Pada dasarnya pemeliharaan kesehatan gigi dan mulut bukanlah sekedar dan sesederhana menggosok gigi 2 kali sehari. Pembersihan rongga mulut hanya sebagian kecil dari upaya preventif untuk mendapatkan kondisi rongga mulut yang sehat sebagai bagian penting dari pertumbuhan dan perkembangan kraniofasial khususnya dan tumbuh anak pada umumnya. ${ }^{14}$

Status gizi merupakan salah satu indikator derajat kesehatan. ${ }^{6}$ Di Indonesia salah satu upaya peningkatan derajat kesehatan yaitu dengan melakukan penilaian terhadap status gizi, lebih khusus kepada masyarakat usia rawan yaitu anak balita. ${ }^{15}$ Penilaian status gizi untuk ukuran dan komposisi tubuh merupakan penilaian status gizi dengan menggunakan pengukuran antropometri.

Pengukuran antropometri diperoleh dari pengukuran berat badan, tinggi badan, dan usia. Salah satu indikator penilaian status gizi dengan menggunakan pengukuran antropometri, yaitu IMT/U. status gizi (IMT/U) murid TK Kartika XX-16 Manado sebagian besar dikategorikan normal.

Dari 48 orang subyek, prevalensi status gizi normal sebesar 93,75\% (45 anak), sedangkan prevalensi bermasalah status gizi sebesar 6,3\% (3 anak). Umumnya status gizi pada masa prasekolah cenderung mengalami gangguan akibat aktivitas yang mulai banyak serta pemilihan dan penolakan terhadap makanan. ${ }^{14}$ Hasil penelitian menunjukkan hal berbeda yang merupakan cerminan keberhasilan program pengembangan fisik yang diterapkan di TK Kartika XX-16 Manado. Salah satu program pengembangan fisik yang dibina bagi murid TK Kartika XX-16 Manado yaitu penjagaan kesehatan melalui konsumsi makanan yang tepat dan berimbang.

Meskipun demikian, masih ditemukan subyek yang bermasalah gizi sebanyak 3 orang dengan prevalensi $6,3 \%$. Pola makan harus tepat dan berimbang. Tepat berarti makanan yang diberikan mengandung zatzat gizi sesuai dengan kebutuhan. Berimbang berarti komposisi zat-zat gizi dalam makanan menunjang proses tumbuh 
kembang. Semakin beragam makanan yang dhidangkan dalam kualitas dan kuantitas yang tepat, semakin baik status gizi anak balita.

Sejalan dengan tujuan khusus program perbaikan gizi di Indonesia, perbaikan status gizi dapat dimulai dengan meningkatkan kernandirian keluarga untuk membentuk perilaku hidup sehat pada anak. Perilaku hidup sehat ditunjang dengan meningkatkan penganekaragaman konsumsi pangan yang bermutu di tingkat rumah tangga dan lingkungan sekolah. Perilaku hidup sehat dan pola makan yang tepat selain dapat meningkatkan perbaikan status gizi, juga membantu membentuk perilaku anak dalam mengatur pola makan kariogenik sehingga mampu mengurangi resiko peningkatan keparahan karies pada gigi sulung. ${ }^{14}$

\section{SIMPULAN}

Berdasarkan hasil penelitian terhadap murid TK Kartika XX-16 Manado dapat disimpulkan bahwa secara umum status karies gigi berdasarkan indeks dmf-t tergolong kategori tinggi sedangkan status gizi berdasarkan indikator IMT/U tergolong kategori normal.

\section{SARAN}

Perlu diupayakan promosi kesehatan untuk memperbaiki masalah karies gigi dan status gizi pada murid TK Kartika XX-16 Manado yang melibatkan orang tua, guru, tenaga kesehatan, dan pemerintah setempat melalui penyuluhan berkala mengenai makanan bergizi dan karies gigi. Juga perlu dilakukan penelitian berkelanjutan terhadap status karies gigi dan status gizi pada anak usia prasekolah.

\section{DAFTAR PUSTAKA}

1. Badan Penelitian dan Pengembangan Kesehatan. Riset Kesehatan Dasar: RISKESDAS 2007. Jakarta: Departemen Kesehatan RI, 2008; p. 36,131 .

2. Badan Penelitian dan Pengembangan Kesehatan. Riset Kesehatan Dasar: RISKESDAS 2013. Jakarta:
Departemen Kesehatan RI, 2013; p. 111, 213.

3. World Healh Organization. Oral Health Surveys Basic Methods (5th ed). France: WHP Press, 2013; p. 13-4, 47, 73-4.

4. Kidd EAM, Bechal SJ. Dasar-dasar Karies: Penyakit dan Penanggulangan (1st ed). Yuwono L, editor. Jakarta: EGC, 1991; p. 2.

5. Ahmad HM. Karies dan Perawatan Pulpa pada Gigi Anak Buku Saku. Jakarta: SagungSeto, 2015 ; p. $54-84$

6. Pusat data dan informasi Depkes. Indikator Indonesia sehat 2010 dan pedoman penetapan indikator provinsi sehat dan kabupaten/kota sehat : keputusan Menteri Kesehatan nomor 1202/ MENKES/SK/VIII/2003. Jakarta: Departemen Kesehatan RI, 2003; p. 1, 9.

7. Dewan Perwakilan Rakyat RI. Undang-undang Republik Indonesia nomor 36 tahun 2009 tentang kesehatan. Jakarta: Departemen Kesehatan RI, 2009.

8. Noya M. Gambaran tingkat karies gigi menurut status gizi anak usia 10-11 tahun di SD Katolik 13 St. Paulus Manado [Skripsi]. Manado: Universitas Sam Ratulangi; 2011.

9. Mendur SCM. Gambaran konsumsi makanan kariogenik pada anak SD GMIM 1 Kawangkoan Manado [Skripsi]. Manado: Universitas Sam Ratulangi; 2016.

10. Embisa YA. Pengaruh konsumsi nanas terhadap penurunan indeks plak pada anak usia 10-12 tahun di SD Inpres 4/82 Pandu Manado [Skripsi]. Manado: Universitas Sam Ratulangi; 2016.

11. Pulu M. Gambaran karies, kebersihan mulut dan kebiasaan menyikat gigi pada murid SD GMIM 21 Eben Haezer Kombos Manado [Skripsi]. Manado: Universitas Sam Ratulangi; 2012.

12. Bermulo H. Gambaran tingkat karies berdasarkan status kebersihan gigi dan mulut pada siswa sekolah dasar di Desa Ranowangko II kecamatan Kombi Manado [Skripsi]. Manado: Universitas Sam Ratulangi; 2011.

13. Inkiriwang RL. Hubungan perasaan dan tingkah laku terhadap dokter gigi dengan status kesehatan gigi dan mulut anak di SD Kartika XX-3 Manado 
Jurnal e-GiGi (eG), Volume 5 Nomor 2, Juli-Desember 2017

[Skripsi]. Manado: Universitas Sam Ratulangi; 2016.

14. Fahlevi R. Rongga Mulut sebagai Bagian Integral Pertumbuhan dan Perkembangan Anak Balita. Buku Kumpulan Tips Pediatrik. Jakarta:
IDAI, 2011; p. 172-7.

15. Hidayat R, Tandiari A. Kesehatan Gigi dan Mulut Apa yang Sebaiknya Anda Tahu? Yogyakarta: Penerbit Andi, 2016; p. 19-53. 